\title{
British fund-raising
}

\section{Hard sell in cancer research}

MAILING shots from a British cancer research charity called the Association for International Cancer Research (AICR) have been descending on surprised members of the British public. The letters begin by inviting recipients to take part in a prize draw, and say that luxury items worth up to $£ 10,000$ are being given away. The letters, carrying a return address at a Cheltenham post office box, are signed by Frank Salisbury, and go on to suggest that appreciative recipients may wish to make donations to AICR's fund for cancer research. Failure to do so, however will not jeopardize chances of winning a prize. A spokesman for the mailing house said this week that the full address was omitted by accident from the first mailing pieces.

The hard sell on behalf of a good cause is unfamiliar in Britain, although the technique of linking a prize draw with a solicitation has also recently been used by the Consumers Association on behalf of its publication Which?. Those familiar with British cancer research charities have also been surprised that AICR's account of recent progress in cancer research closely follows a document put out last year by the Cancer Research Campaign.

AICR began life in December 1979 as NFCR-UK, a British spin-off of a US organization, the National Foundation for Cancer Research (NFCR). The declared objectives of NFCR-UK were to "promote, conduct and support research into the causes, prevention, treatment and cure of cancer and associated conditions". The directors were Franklyn Salisbury, his wife Tamara, Professor Kenneth Rees of University College London and Professor Trevor Slater of the department of biochemistry at Brunel University.

At an extraordinary general meeting in December 1982 , it was decided to change the name to AICR. The recent mail-shot seems to reflect AICR's wish to sustain itself through "our own fund-raising efforts in the UK"'. At the outset, NFCR-UK received $£ 450,000$ from its US parent organization. Since then, annual expenditure on grants has not exceeded accrued annual interest. The mail-shot describes recent developments in cancer research in a manner which, by elisions of syntax and layout, prompts the inference that AICR is responsible.

NFCR was set up ten years ago in the United States by Salisbury, an east coast lawyer, with the help of Dr Albert SzentGyorgyi, the Nobel laureate. Last year, Salisbury was granted an audience with the Pope in recognition of services to cancer research in Italy. Later this year, he will be awarded an honorary degree by the University of Wales. His present involvement with AICR may explain the aggressive style of its fund-raising campaign. NFCR has made grants to more than 80 laboratories in 15 countries. Its international status has complicated its task of complying with US regulations governing charities which, inter alia, require that each year's income should be spent or overspent in the year in which it is earned.

From its inception, AICR has been coordinated from Brunel University. Professor Robin Willson, whose research there into the interaction of certain drugs with oxygen-free radicals has been supported by NFCR, explains that a decision was made at the last annual general meeting to relocate AICR's administrative centre at the University of St Andrews, under the auspices of Dr Colin Thomson.

Dr Thomson says that the prize-draw invitations were sent out to 400,000 members of the public believed to be susceptible to mail-order solicitations. According to $\mathrm{Dr}$ Thomson, an additional leaflet outlining recent scientific advances was sent out to 10 per cent of those on the mailing list, but as an experiment.

When asked why AICR had embarked on this campaign after four and a half years of relative inactivity, he replied that "the previous board didn't think it would work here. The kind of reaction one is inevitably going to get from the established groups is that we're only interested in the kinky fringes of science. In fact we aim to focus attention on novel and under-investigated areas of research."

Professor Willson, however, fears that AICR's new tactics may detract from the work of established groups. "Our only doubts about raising funds in Britain are that we do not wish to tread on the toes of the Institute of Cancer Research and the Cancer Research Campaign." Dr Thomson dismisses this concern; "we're trying to support good science, high-quality research which is not competitive but complementary",

Apart from research supported by the British fund, some groups continue to be supported directly from the United States. Dr Ronald Pethig of the University College of North Wales at Bangor says that the US fund has supported his investigation of cell membrane structure to the tune of $£ 40,000$ a year for several years generously and flexibly.

On the telephone from Washington this week, Mr Salisbury said that the "British people are responding nicely" to the recent mail-shot. He explained that he had decided that the time had come to make the British offshoot "more active", but that there were limits to the extent to which cancer could be dealt with "by throwing money at it"'. The British trustees, apart from Mr Salisbury himself, are Dr Colin Thomson and Professor Lord Tedder, also at St Andrews.

\section{AMPTE \\ British component fails}

To the bitter disappointment of British space scientists, the United Kingdom's component of the AMPTE (Active Magnetospheric Particle Tracer Explorers) mission appears to have ended prematurely. The UK Subsatellite (UKS) is equipped to measure the particles and the magnetic and electric fields and waves encountered as it follows its West German companion satellite in an orbit through the magnetosphere. But on 16 January, the Rutherford Appleton Laboratory failed to detect a signal from UKS as it came over the horizon; subsequent efforts suggest that the fault lies in the spacecraft itself and is irremediable.

The AMPTE mission achieved two major successes during earlier experiments, in which lithium and barium ions were released in the solar wind upstream of the Earth's magnetosphere. The German satellite, the Ion Release Module (IRM), and UKS were able to monitor the cometlike interactions which followed the releases (see Nature 10 January, p.90). The third AMPTE satellite, the US Charge Composition Explorer (CCE), is placed in an orbit within the radiation belts and, as well as continually monitoring the particle populations, is also hoped to detect any ions that might be injected into the belts following their release from IRM.
Earlier this month, British scientists were cock-a-hoop over the quality of data coming in from UKS. Following the disappearance of the signal, a search for the satellite has been carried out by the National Aeronautics and Space Administration's deep space network and other facilities. One possibility being considered was that the spacecraft had changed orbit due to an unplanned expulsion of gas. This is now ruled out. No signal has been detected and, after extensive checks of ground equipment, it has been concluded that the fault is on board.

According to a spokesman at the Rutherford Appleton Laboratory, the mission has achieved 70 per cent of its aims. One of those involved in the mission, David Southwood of Imperial College, London, expressed considerable frustration that UKS did not hold out until its orbit had precessed into the magnetotail, where a plasma release is planned. "Had it lasted until May or June it would have achieved 90 to 95 per cent of its aims" he said. "But the data sent back from the magnetopause [the boundary between the solar wind and the Earth's magnetosphere] are, in terms of time and angular resolution, the best achievable for some time to come, while the comet release experiments were unique."

Philip Campbel 